\title{
Embryonic development and incidence of aneuploidy in two rabbit strains of different fecundity
}

\author{
B. Fischer* and A. Schumacher \\ Department of Anatomy and Reproductive Biology, Medical Faculty, RWTH Aachen, \\ D-5100 Aachen, Federal Republic of Germany
}

\begin{abstract}
Summary. The correlation between strain fecundity and (i) development and (ii) rate of aneuploidy was studied in rabbit preimplantation embryos obtained from 2 strains of different fecundity. Embryos were investigated at Days 3-6 (preimplantation development) or Days 2, 4 and 6 post coitum (aneuploidy). Embryonic size and cell proliferation varied on the days of investigation, but with no consistent tendency in favour of one strain. The incidence of aneuploidy did not differ significantly between embryos from the 2 strains $(P>0.05)$. The multifactorially determined criterion of prolificacy was not selectively correlated with overall differences in embryonic preimplantation growth and rate of aneuploidy.
\end{abstract}

Keywords: preimplantation development; aneuploidy; fecundity; strain differences; rabbit

\section{Introduction}

The speed of preimplantation embryo development is genetically influenced. The most well-known example is a gene, Ped, located within the major histocompatibility complex (MHC) in mice (Goldbard \& Warner, 1982; see Warner, 1986; Warner et al., 1987a, b, 1988). In pigs an MHClinked gene is associated with number of cells (Ford et al., 1988) and survival (Conley et al., 1988) of preimplantation embryos. Speed of development is supposed to be an essential expression of embryo viability. It has been shown, in a range of species, that rapidly dividing and advanced embryos have the best potential for further development and/or survival to term (human: Mohr et al., 1983; Claman et al., 1987; rhesus monkey: Bavister et al., 1983; cattle: Renard et al., 1977; Renard \& Heyman, 1979; pig: Pope et al., 1982, 1986; Wilmut et al., 1985, 1986; Bazer et al., 1988; rabbit: Hafez, 1962; Torres et al., 1987a, b; mouse: Tsunoda et al., 1985; Baunack et al., 1986). Thus, differences in the rate of preimplantation development may contribute to the higher prolificacy of breeds or strains.

Findings in rabbits (Torres et al., 1987a, b) indicate that embryo development during the first days of preimplantation development may be most directly linked to strain fecundity. Up to Day 4 post coitum (p.c.) a clear difference in ovulation rate between Californian $(11.6 \pm 0.2)$ and New Zealand $(9.7 \pm 0.2)$ rabbit strains became equalized to 8.9 and 8.2 embryos per female, respectively, the approximate litter size at birth (Torres et al., 1987a). Diameters were statistically significantly larger in blastocysts from New Zealand does, the strain with the lower percentage of embryonic loss. Similar differences in ovulation rate and embryonic survival are known between Large White and Meishan pig breeds (Bazer et al., 1988). The latter has fewer ovulations but larger and more uniformly sized conceptuses and less embryonic wastage, resulting in more piglets/litter in Meishan gilts than in Large White. In pigs, however, the significant differences in conceptus size between the breeds appeared in the second half of preimplantation development, closer to the time of implantation. The reports in rabbits and pigs were based on a limited number of observations. In

*Reprint requests. 
the present study, employing more females and embryos, we tried to determine whether embryo development during later stages of the preimplantation period may also be related to higher fecundity in rabbits. We studied 2 strains which, after treatment of the females with folliclestimulating hormone (FSH) differed in the mean number of preimplantation embryos by 10 .

The incidence of aneuploidy was investigated in embryos from these strains. Aneuploidy is an important genetic disorder in mammalian embryos (see de Boer et al., 1986 and Bolet, 1986) and may thus contribute considerably to embryonic loss and fecundity. Unlike previous studies (see Delbos-Winter et al., 1987), the incidence of aneuploidy was studied in rabbit embryos of a fairly well-defined genetic background obtained on consecutive days of the preimplantation period. The percentages of aneuploid embryos and aneuploid cells per embryo were analysed.

\section{Materials and Methods}

Donors and embryos. Reproductive data were for 208 females. Embryos from 98 donor does were allocated for analysis of cell proliferation by incorporation of tritiated thymidine (in embryos 3-6 days old), diameter (in blastocysts 4-6 days old) and aneuploidy (in embryos 2, 4 or 6 days old). The high number of females was chosen to minimize donor effects. The does were killed at the various days indicated to obtain embryos. Not all embryos recovered were used in the present study: only those of normal morphology, randomly selected among litter mates and coded for blind reading, were analysed. Details regarding housing of the rabbits, superovulation treatment of the donors with FSH and embryo recovery are described by Fischer (1987) and Fischer \& Meuser-Odenkirchen (1988); and regarding evaluation of morphology, measurement of diameter and thymidine incorporation by Fischer (1989).

\footnotetext{
Animals. The rabbits used for this study were commercial hybrids of high prolificacy (ZIKA-hybrids; basic seedstock: Dr Zimmermann, D-7083 Untergröningen, FRG) and outbreds from a fancy breed (Alaska) purchased from a local breeder. The hybrids were supplied by an intermediate seedstock producer. Typically, the females are sold to commercial farms as a maternal line (selected for maternal characters) for crossbreeding with a specific paternal line to produce offspring for meat production. The males used for the present study were also derived from the seedstock producer's maternal line. The male and female outbreds came from a stock from does bred within the colony and bucks from outside the colony. In non-FSH-primed females, there were $10 \cdot 3$ ovulations in the hybrids ( $n=48$ females) and 7.9 in the outbreds $(n=8 ; P<0.05)$. As stated by the suppliers, the average number of live young at birth is 8.4 for the hybrids and $\leqslant 7$ for the outbreds. The rabbits were bought at least 14 days prior to experiments and kept under the same conditions. At autopsy, corpora lutea were counted in isolated ovaries. Ovulations $>20$ are macroscopically not accurately countable and were computed as 20 ovulations.
}

Analysis of DNA content. The method used for analysing the DNA content in embryonic cell nuclei is that described by A. Schumacher, T. Agorastos, B. Fischer and H. M. Beier (unpublished). Briefly, after dissolution of the zona pellucida with $0.5 \%$ pronase, the embryos were exposed to a hypotonic shock, spread individually on microscope slides, fixed, air dried for $24 \mathrm{~h}$ and Feulgen-stained according to Bolton et al. (1984). The amount of DNA was measured cytophotometrically against simultaneously stained vaginal smears as calibration standard. Cytometry was performed on a television-based image-analysis system combined with an automatic microscope (Miamed, Leitz, FRG; Auffermann et al., 1984). Nuclei were considered aneuploid with $\geqslant 5 \mathrm{c}$ DNA. In Day 2 embryos, the nuclei of all blastomeres were measured and, in Day 4 and Day 6 blastocysts, nuclei of 100 cells/blastocyst were measured.

Statistical analysis. Diameters, thymidine incorporation and number of aneuploid cells/embryo were analysed by Student's $t$ test; comparisons of strain prolificacy and incidence of aneuploid embryos by $\chi^{2}$ test with Yates' correction (Sachs, 1984).

\section{Results}

Reproductive performance up to Day 6 p.c., i.e. immediately before implantation, was clearly different between females from the 2 strains (Table 1). The hybrid does yielded 10 preimplantation embryos more than the outbreds, mainly caused by a higher number of ovulations and better embryonic survival.

Size and thymidine incorporation in embryos from both strains, either from pure breeds or from reciprocal crossbreds, are summarized in Tables 2 and 3. Although variation occurred at the 
Table 1. Reproductive performance of ZIKA hybrid and Alaska outbred rabbits after preovulatory treatment with follicle-stimulating hormone*

\begin{tabular}{lcc}
\hline & Hybrid & Outbred \\
\hline $\begin{array}{l}\text { Females without ovulation } \\
(\%)\end{array}$ & $2^{\mathrm{a}}$ & $10^{\mathrm{b}}$ \\
$N$ & 116 & 92 \\
$\begin{array}{l}\text { No. of corpora lutea/ } \\
\text { female }\end{array}$ & $32 \cdot 7 \pm 0 \cdot 8^{\mathrm{c}}$ & $28 \cdot 5 \pm 1 \cdot 1^{\mathrm{d}}$ \\
$N$ & 114 & 83 \\
$\begin{array}{l}\text { Females without embryo } \\
\text { recovery (\%) }\end{array}$ & $3^{\mathrm{e}}$ & $6^{\mathrm{e}}$ \\
$\begin{array}{l}\text { No. of embryos/female } \\
\text { Total }\end{array}$ & $28 \cdot 0 \pm 1 \cdot 6^{\mathrm{c}}$ & $20 \cdot 1 \pm 1.7^{\mathrm{d}}$ \\
$N$ & 111 & 78 \\
Degenerated & $3 \cdot 5 \pm 0 \cdot 5^{\mathrm{e}}$ & $4 \cdot 3 \pm 1 \cdot 0^{\mathrm{e}}$ \\
Embryo survival (\%) & 75 & 55 \\
No. of nondegenerated & & \\
$\quad$ embryos/femalet & $23 \cdot 3$ & $13 \cdot 3$ \\
$N$ & 116 & 92 \\
\hline
\end{tabular}

*Cumulative data from Days 3 to 6 p.c.

†Mean number of embryos for all females in study.

Values are given as means \pm s.e.m.; $N=$ number of females. a vs. b $P<0.05$; c vs. d $P<0.01$; e $P>0.05$.

different days of observation, there was no consistent tendency in favour of one strain or strain combination during the second half of preimplantation.

The incidence of aneuploid embyros was not statistically significantly different between the two strains, but it increased remarkably from Day 2 to Day 6 p.c. (Table 4). The mean number of aneuploid cells/embryo was generally low: $2.7 \pm 0.9(\bar{x} \pm$ s.e.m.) in hybrid and $4.1 \pm 1.2$ in outbred embryos $(P>0 \cdot 05)$.

\section{Discussion}

Embryo viability is one determinant of prolificacy. In the present study, using rabbit strains differing in reproductive performance (see Table 1) and high numbers of females and embryos, an interrelation between growth of preimplantation embryos (Tables 2,3), incidence of aneuploidy (Table 4) and strain prolificacy was not demonstrated.

In the experiments reported by Torres et al. $(1987 \mathrm{a}, \mathrm{b})$, the strain with the most ovulations had the highest percentage of embryonic loss. The better prolificacy of the hybrid strain in the present investigation was based on more ovulations as well as on superior embryonic survival (Table 1). These results indicate that, in rabbits (i) higher ovulation rates are not always associated with a higher incidence of preimplantation embryonic loss and (ii) both criteria can obviously be improved, even simultaneously, by genetic selection.

Torres et al. (1987b) concluded that the major embryonic loss occurs early in pregnancy, as failure of fertilization and/or by retardation in cleavage. However, in a previous study, embryo mortality in FSH-primed rabbits was notably higher in blastocysts than in cleavage stages (Fischer \& Meuser-Odenkirchen, 1988). In the present study, this finding was confirmed for early blastocysts at Day 4 p.c. but not for later stages, probably because of the limited number of females involved (data not given). In addition, a significant percentage of prenatal mortality occurs 
Table 2. Diameters $(\mathrm{mm})$ of blastocysts from crosses of ZIKA hybrid $(\mathrm{H})$ and Alaska outbred (L) rabbits

\begin{tabular}{|c|c|c|c|c|c|c|c|c|}
\hline \multirow{2}{*}{$\begin{array}{l}\text { Embryonic age } \\
\text { (days p.c.) }\end{array}$} & \multicolumn{2}{|c|}{$\mathrm{H}_{3}^{*} \times \mathrm{H}_{7}$} & \multicolumn{2}{|c|}{$\mathrm{L} 3 \times \mathrm{H}_{7}$} & \multicolumn{2}{|c|}{$\mathrm{H}_{3} \times \mathrm{L}_{f}$} & \multicolumn{2}{|c|}{$\mathrm{L}_{3} \hat{3} \times \mathrm{L}_{7}$} \\
\hline & Mean & s.e.m. & Mean & s.e.m. & Mean & s.e.m. & Mean & s.e.m. \\
\hline 4 & $0 \cdot 34^{\mathrm{a}}$ & 0.01 & $0 \cdot 28^{\mathrm{b}}$ & $0 \cdot 001$ & $0 \cdot 32$ & 0.02 & $0 \cdot 34^{\mathrm{a}}$ & $0 \cdot 01$ \\
\hline$n$ & \multicolumn{2}{|c|}{107} & \multicolumn{2}{|c|}{94} & \multicolumn{2}{|c|}{32} & \multicolumn{2}{|c|}{106} \\
\hline$N$ & \multicolumn{2}{|c|}{5} & \multicolumn{2}{|c|}{12} & \multicolumn{2}{|c|}{4} & \multicolumn{2}{|c|}{6} \\
\hline 5 & $0.89^{\mathrm{c}}$ & 0.02 & $1.05^{\mathrm{d}}$ & $0 \cdot 02$ & $1 \cdot 07^{\mathrm{d}}$ & 0.04 & $1 \cdot 09^{\mathrm{c}}$ & $0 \cdot 06$ \\
\hline$n$ & \multirow{2}{*}{\multicolumn{2}{|c|}{$\begin{array}{r}78 \\
3\end{array}$}} & \multirow{2}{*}{\multicolumn{2}{|c|}{. $\begin{array}{r}240 \\
9\end{array}$}} & \multirow{2}{*}{\multicolumn{2}{|c|}{$\begin{array}{r}60 \\
2\end{array}$}} & \multirow{2}{*}{\multicolumn{2}{|c|}{$\begin{array}{r}28 \\
2\end{array}$}} \\
\hline$N$ & & & & & & & & \\
\hline 6 & $2 \cdot 70$ & 0.08 & $2 \cdot 80$ & $0 \cdot 11$ & $2 \cdot 81$ & 0.06 & $2 \cdot 69$ & 0.07 \\
\hline$n$ & \multicolumn{2}{|c|}{87} & \multicolumn{2}{|c|}{49} & \multicolumn{2}{|c|}{47} & \multicolumn{2}{|c|}{123} \\
\hline$N$ & \multicolumn{2}{|c|}{4} & \multicolumn{2}{|c|}{2} & \multicolumn{2}{|c|}{3} & \multicolumn{2}{|c|}{5} \\
\hline
\end{tabular}

$\mathrm{H}=$ highly prolific, $\mathrm{L}=$ low prolificacy.

$n=$ number of blastocysts, $N=$ number of females.

a vs. b, c vs. d $P<0.01 ;$ c vs. e $P<0.001$; all other comparisons $P>0.05$.

Table 3. Thymidine incorporation (d.p.m./embryo) in embryos from crosses of ZIKA hybrid $(\mathrm{H})$ and Alaska outbred $(\mathrm{L})$ rabbits

\begin{tabular}{|c|c|c|c|c|c|c|c|c|}
\hline \multirow{2}{*}{$\begin{array}{l}\text { Embryonic age } \\
\text { (days p.c.) }\end{array}$} & \multicolumn{2}{|c|}{$\mathbf{H}_{3} \times \mathrm{H}_{7}$} & \multicolumn{2}{|c|}{$\mathrm{L}_{3} \times \mathrm{H}_{7}$} & \multicolumn{2}{|c|}{$\mathrm{H}_{3} \times \mathrm{L}_{7}$} & \multicolumn{2}{|c|}{$\mathrm{L}_{\hat{j}} \times \mathrm{L}_{\mathbf{I}}$} \\
\hline & Mean & s.e.m. & Mean & s.e.m. & Mean & s.e.m. & Mean & s.e.m. \\
\hline 3 & $415^{a}$ & 21 & $465^{a}$ & 24 & $403^{a}$ & 43 & $745^{b}$ & 53 \\
\hline$n$ & \multicolumn{2}{|c|}{68} & \multicolumn{2}{|c|}{91} & \multicolumn{2}{|c|}{45} & \multicolumn{2}{|c|}{64} \\
\hline$N$ & \multicolumn{2}{|c|}{3} & \multicolumn{2}{|c|}{8} & \multicolumn{2}{|c|}{4} & \multicolumn{2}{|c|}{7} \\
\hline 4 & $4301^{\mathrm{c}}$ & 215 & $3480^{\circ}$ & 189 & 3767 & 380 & $4320^{\mathrm{c}}$ & 181 \\
\hline$n$ & \multirow{2}{*}{\multicolumn{2}{|c|}{$\begin{array}{r}86 \\
3\end{array}$}} & \multirow{2}{*}{\multicolumn{2}{|c|}{$\begin{array}{l}94 \\
12\end{array}$}} & \multirow{2}{*}{\multicolumn{2}{|c|}{$\begin{array}{r}30 \\
4\end{array}$}} & \multirow{2}{*}{\multicolumn{2}{|c|}{$\begin{array}{r}64 \\
3\end{array}$}} \\
\hline$N$ & & & & & & & & \\
\hline \multirow{3}{*}{$\begin{array}{l}n \\
N\end{array}$} & $20988^{\mathrm{e}}$ & 1383 & $33182^{\mathrm{f}}$ & 1235 & $43233^{\mathrm{g}}$ & 3006 & $33340^{\mathrm{h}}$ & 3411 \\
\hline & \multirow{2}{*}{\multicolumn{2}{|c|}{$\begin{array}{r}82 \\
3\end{array}$}} & \multirow{2}{*}{\multicolumn{2}{|c|}{$\begin{array}{r}237 \\
7\end{array}$}} & \multirow{2}{*}{\multicolumn{2}{|c|}{$\begin{array}{r}57 \\
3\end{array}$}} & \multirow{2}{*}{\multicolumn{2}{|c|}{$\begin{array}{r}28 \\
2\end{array}$}} \\
\hline & & & & & & & & \\
\hline \multirow[b]{3}{*}{$N$} & $157154^{i}$ & 10383 & 182264 & 12633 & $215925^{\mathrm{k}}$ & 15228 & $153603^{1}$ & 8075 \\
\hline & \multirow{2}{*}{\multicolumn{2}{|c|}{$\begin{array}{r}57 \\
2\end{array}$}} & \multicolumn{2}{|c|}{46} & \multicolumn{2}{|c|}{40} & \multicolumn{2}{|c|}{66} \\
\hline & & & \multicolumn{2}{|c|}{2} & \multicolumn{2}{|c|}{3} & \multicolumn{2}{|c|}{2} \\
\hline
\end{tabular}

$\mathrm{H}=$ highly prolific, $\mathrm{L}=$ low prolificacy.

$n=$ number of embryos, $N=$ number of females.

g vs. h $P<0.05$; c vs. d, e vs. h, f vs. g, i vs. k $P<0.01$; a vs. b, evs. f, e vs. g, k vs. I $P<0.001$; all other comparisons $P>0.05$.

after implantation. Early work by Adams, including superovulated (1960a) and nonprimed rabbits $(1960 \mathrm{~b})$, exhibited almost a doubling in mortality after implantation $(\sim 18 \%)$ compared with preimplantation loss $(\sim 10 \%)$, demonstrating the decisive importance of postimplantation development for the final number of young born.

Metabolic criteria may be more directly linked with developmental potential than growth and cell proliferation although, with notable exceptions, both properties seem to be related. Van der Meulen et al. (1989) recently reported a positive relationship between aromatase activity and diameter in pig blastocysts, but emphasized that there were considerable individual variations. In normal rabbit blastocysts, DNA and protein synthesis are highly correlated with diameter, but not in blastocysts damaged by culture in serum-supplemented media (Jung \& Fischer, 1988). Among quantitative parameters, qualitative differences have to be noted. For example, blastocysts of the same size differ considerably in number of embryoblast cells (pig: Barends et al., 1989; mouse: 
Table 4. Incidence of aneuploidy $(\%)$ in embryos from ZIKA hybrid $(\mathrm{H})$ and Alaska outbred (L) rabbits

\begin{tabular}{|c|c|c|}
\hline $\begin{array}{l}\text { Embryonic age } \\
\text { (days p.c.) }\end{array}$ & $\mathbf{H}_{3} \times \mathbf{H}_{\uparrow}$ & $\mathrm{L}_{3}^{*} \times \mathrm{Lq}$ \\
\hline $\begin{array}{l}2 \\
\quad n \\
N\end{array}$ & $\begin{array}{r}11 \\
19 \\
3\end{array}$ & $\begin{array}{r}16 \\
31 \\
4\end{array}$ \\
\hline$n$ & $\begin{array}{r}29 \\
28 \\
8\end{array}$ & $\begin{array}{r}20 \\
40 \\
8\end{array}$ \\
\hline $\begin{array}{l}n \\
N\end{array}$ & $\begin{array}{r}58 \\
24 \\
3\end{array}$ & $\begin{array}{r}46 \\
26 \\
4\end{array}$ \\
\hline $\begin{array}{c}2,4 \text { and } 6 \\
n \\
N\end{array}$ & $\begin{array}{l}34 \\
71 \\
14\end{array}$ & $\begin{array}{l}26 \\
97 \\
16\end{array}$ \\
\hline
\end{tabular}

Chisholm et al., 1985). Studies in rabbit blastocysts, however, could prove that a threshold value for a minimal number of embryoblast cells has to be guaranteed to secure further development (Mootz, 1971). Therefore, valid criteria for judgement of embryo viability still have to be defined and might be more closely linked to strain prolificacy than the criteria presently investigated.

The percentage of aneuploid embryos found in the present study (Table 4) (i) was not influenced by maternal FSH treatment and (ii) was higher than in other studies (A. Schumacher, T. Agorastos, B. Fischer and H. M. Beier, unpublished). Apart from a few blastocysts, all from Day 6 p.c., the number of aneuploid cells per embryo was too low to be considered as a major reason for embryonic mortality during preimplantation development. We conclude that the higher reproductive performance in the hybrid strain studied cannot be traced back selectively to a generally advanced early embryonic development or reduced rate of aneuploidy. Other reasons, e.g. number of ovulations, maternally determined developmental conditions, implantation and postimplantation development, will have to be considered to define more closely the actual determinants of fecundity.

We thank Professor A. Böcking, Department of Pathology, Medical Faculty, RWTH Aachen, for the generous supply of the Miamed set-up and for helpful advice, Sabine Gülpen for expert assistance, Professor B. D. Bavister, Department of Veterinary Science, University of Wisconsin, Madison, for his comments on the manuscript, and Ria Becht and Gisela Mathieu for typing the manuscript.

\section{References}

Adams, C.E. (1960a) Studies on prenatal mortality in the rabbit, Oryctolagus cuniculus: the amount and distribution of loss before and after implantation. $J$. Endocr. 19, 325-344.

Adams, C.E. (1960b) Prenatal mortality in the rabbit Oryctolagus cuniculus. J. Reprod. Fert. 1, $36-44$.

Auffermann, W., Repges, R. \& Böcking, A. (1984) Rapid diagnosis DNA cytometry with an automatic micro- scope and a TV image-analysis system. Analyt. quant. Cytol. 6, 179-188.

Barends, P.M.G., Stroband, H.W.J., Taverne, N., te Kronnie, G., Leën, M.P.J.M. \& Blommers, P.C.J. (1989) Integrity of the preimplantation pig blastocyst during expansion and loss of polar trophectoderm (Rauber cells) and the morphology of the embryoblast as an indicator for developmental stage. $J$. Reprod. Fert. 87, 715-726. 
Baunack, E., Wieding, B. \& Gärtner, K. (1986) Prenatal survival frequency of reciprocal $F 1$-hybrids in inbred mice caused both by embryonic factors and genotype of foster mother. Zuchthyg. 21, 115-120.

Bavister, B.D., Boatman, D.E., Leibfried, L., Loose, M. \& Vernon, M.W. (1983) Fertilization and cleavage of rhesus monkey oocytes in vitro. Biol. Reprod. 28, 983-999.

Bazer, F.W., Thatcher, W.W., Martinat-Botte, F. \& Terqui, M. (1988) Conceptus development in Large White and prolific Chinese Meishan pigs. J. Reprod. Fert. 84, 37-42.

de Boer, P., van der Hoven, F.A. \& Cuijpers, M.P. (1986) Genetic constitution of early stage pig embryos and embryo mortality. In Embryonic Mortality in Farm Animals, pp. 207-215, Eds J. M. Sreenan \& M. G. Diskin. Martinus Nijhoff, Dordrecht.

Bolet, G. (1986) Timing and extent of embryonic mortality in pigs, sheep and goats: genetic variability. In Embryonic Mortality in Farm Animals, pp. 12-43, Eds J. M. Sreenan \& M. G. Diskin. Martinus Nijhoff, Dordrecht.

Bolton, V.N., Oades, P.J. \& Johnson, M.H. (1984) The relationship between cleavage, DNA replication, and gene expression in the mouse 2-cell embryos. $J$. Embryol. exp. Morph. 79, 139-163.

Chisholm, J.C., Johnson, M.H., Warren, P.D., Fleming, T.P. \& Pickering, S.J. (1985) Developmental variability within and between mouse expanding blastocysts and their ICMs. J. Embryol. exp. Morph. 86, 311-336.

Claman, P., Armant, D.R., Seibel, M.M., Wang, T.-A., Oskowitz, S.P. \& Taymor, M.L. (1987) The impact of embryo quality and quantity on implantation and the establishment of viable pregnancies. $J$. In Vitro Ferilization Embryo Transfer 4, 218-222.

Conley, A.J., Jung, Y.C., Schwartz, N.K., Warner, C.M., Rothschild, M.F. \& Ford, S.P. (1988) Influence of SLA haplotype on ovulation rate and litter size in miniature pigs. J. Reprod. Fert. 82, 595-601.

Delbos-Winter, R., Fischer, B. \& Beier, H.M. (1987) Einflüsse der FSH-/hCG-stimulierten Polyovulation auf Uterussekretion und Implantation beim Kaninchen. Fertilität 3, 87-93.

Fischer, B. (1987) Development retardation in cultured preimplantation rabbit embryos. J. Reprod. Fert. 79, 115-123.

Fischer, B. (1989) Effects of asynchrony on rabbit blastocyst development. J. Reprod. Fert. 86, 479-491.

Fischer, B. \& Meuser-Odenkirchen, G. (1988) A two year follow-up of effects of biotechniques on reproduction in the domestic rabbit, Oryctolagus cuniculus. Lab. Anim. 22, 5-15.

Ford, S.P., Schwartz, N.K., Rothschild, M.F., Conley, A.J. \& Warner, C.M. (1988) Influence of SLA haplotype on preimplantation embryonic cell number in miniature pigs. J. Reprod. Fert. 84, 99-104.

Goldbard, S.B. \& Warner, C.M. (1982) Genes affect the timing of early mouse embryo development. Biol. Reprod. 27, 419 - 424.

Hafez, E.S.E. (1962) Differential cleavage rate in 2-day litter mate rabbit embryos. Proc. Soc. exp. Biol. 110, $142-145$.

Jung, T. \& Fischer, B. (1988) Correlation between blastocyst diameter and DNA or protein synthetic activity in rabbit blastocysts. Biol. Reprod. 39, 1111-1116. van der Meulen, J., te Kronnie, G., van Deursen, R. \& Geelen, J. (1989) Aromatase activity in individual Day-11 pig blastocysts. J. Reprod. Fert. 87, 783-788.

Mohr, L.R., Trounson, A.O., Leeton, J.F. \& Wood, C. (1983) Evaluation of normal and abnormal human embryo development during procedures in vitro. In Fertilization of the Human Egg in vitro, pp. 211-221, Eds H. M. Beier \& H. R. Lindner. Springer-Verlag, Berlin.

Mootz, U. (1971) Die Regulationsbefähigung der Keimscheibe von Oryctolagus cuniculus nach totaler Röntgenbestrahlung. Zool. Jb. Anat. 88, 587-682.

Pope, W.F., Maurer, R.R. \& Stormshak, F. (1982) Survival of porcine embryos after asynchronous transfer. Proc. Soc. exp. biol. Med. 171, 179-183.

Pope, W.F., Lawyer, M.S., Nara, B.S. \& First, N.L. (1986) Effect of asynchronous superinduction on embryo survival and range of blastocyst development in swine. Biol. Reprod. 35, 133-137.

Renard, J.P. \& Heyman, Y. (1979) Variable development of superovulated bovine embryos between day 6 and day 12. Ann. Biol. anim. Biochem. Biophys. 19, $1589-1598$.

Renard, J.P., Heyman, Y., du Mesnil du Buisson, F. \& Pierre, Y. (1977) Unilateral and bilateral cervical transfer of bovine embryos at the blastocyst stage. Theriogenology 7, 189-193.

Sachs, L. (1984) Applied Statistics. Springer-Verlag, Berlin.

Torres, S., Hulot, F., Meunier, M. \& Sevellec, C. (1987a) Comparative study of preimplantation development and embryonic loss in two rabbit strains. Reprod. Nutr. Develop. 27, 707-714.

Torres, S., Hulot, F. \& Sevellec, C. (1987b) Early stages of embryonic development in two rabbit genotypes. Reprod. Nutr. Develop. 27, 715-719.

Tsunoda, Y., Tokunaga, T. \& Sujie, T.C. (1985) Altered sex ratio of live young after transfer of fast- and slow-developing mouse embryos. Gamete Res. 12, 301-304.

Warner, C.M. (1986) Genetic manipulation of the major histocompatibility complex. J. Anim. Sci. 63, 279-287.

Warner, C.M., Gollnick, S., Flaherty, L. \& Goldbard, S.B. (I987a) Analysis of Qa-2 antigen expression by preimplantation mouse embryos: possible relationship to the preimplantation-embryo-development $(P e d)$ gene product. Biol. Reprod. 36, 611-616.

Warner, C.M., Gollnick, S. \& Goldbard, S.B. (1987b) Linkage of the preimplantation-embryo-development $(P e d)$ gene to the mouse major histocompatibility complex (MHC). Biol. Reprod. 36, 606-610.

Warner, C.M., Brownwell, M.S. \& Ewaldsen, M.A. (1988) Why aren't embryos immunologically rejected by their mothers? Bioi. Reprod. 38, 17-30.

Wilmut, I., Sales, D.I. \& Ashworth, C.J. (1985) The influence of variation in embryo stage and maternal hormone profiles on embryo survival in farm animals. Theriogenology 23, 107-119.

Wilmut, I., Sales, D.I. \& Ashworth, C..J. (1986) Maternal and embryonic factors associated with prenatal loss in mammals. J. Reprod. Fert. 76, 851-864. 